\title{
Theories and Practices in Critical Language Teaching: A Dialogic Introduction
}

\author{
Brian Morgan* \\ *Glendon College, York University , Toronto / Canada \\ bmorgan@yorku.ca \\ Andréa Mattos** \\ **Federal University of Minas Gerais, Belo Horizonte, Minas Gerais / Brazil \\ andreamattos@ufmg.br
}

\section{Introduction}

The notion of dialogue in this introductory title suggests a number of productive ambiguities, particularly for critical theories and practices pertaining to second/additional language teaching. In Dialogic Approaches to TESOL: Where the Ginkgo Tree Grows, author Shelley Wong (2011) details the philosophical roots of dialogism running through many traditions and paradigms (e.g. Confucianism, Socratic thought, Marxism), and informing an array of literary, cognitive, educational and socio-political positions in the works of Bakhtin, Vygotsky, and Mao Zedong. Of course, in the context of a special issue of the Brazilian Journal of Applied Linguistics / Revista Brasileira de Linguistica Aplicada (RBLA), the legacy of Paulo Freire is especially relevant. His conceptualization of dialogue as praxis_ of action aligned with reflection-illuminates the ways in which situated literacies and pedagogies can provide an evaluative lens upon the theories that underpin them, which in turn, encourage language specialists to seek out new conceptual frames through which critical language teaching may be invigorated and made more relevant to current times and challenges.

The notion of dialogue can also be diachronic and genealogical (cf. Foucault), a critical questioning of the emergence of norms and "best practices" within a field or area of specialization (e.g., critical language teaching) leading to subsequent efforts to reform and expand the scope of previous work, often through inter/transdisciplinary borrowings, new epistemologies and materialities (DOUGLAS FIR GROUP, 2016; 
APPLEBY; PENNYCOOK, 2017; RAJAGOPALAN, 2008). Through the wisdom - and occasional impatience - of hindsight, critical language researchers and practitioners recognize a strong legacy to build on, but also recognize emerging challenges in understanding new configurations of language and power and the practical and ethical constraints that arise in local settings (see e.g., CHUN; MORGAN, forthcoming; CROOKES, 2013; JANKS, 2014; JORDÃO, 2016; JORDÃO; MARTINEZ; MONTEMOR, 2018; KUBOTA; MILLER, 2017; MATTOS, 2018; NORTON; TOOHEY, 2004; PENNYCOOK, 2001; 2016; PESSOA; SILVESTRE; MONTE-MOR, 2018). Critical work, of necessity, continues to be "on the move" (PENNYCOOK, 2012), with notable developments in areas related to post-colonialism (ANDREOTTI; MENEZES DE SOUZA, 2012; LÓPEZ- GOPAR, 2016), indigeneity (ANDREOTTI; MENEZES DE SOUZA, 2008; KASUN; SAAVEDRA, 2016) and ecological metaphors and principles (cf. "Problems, Difficulties, New Directions" in STEFFENSEN; KRAMSCH, 2017; see also MORGAN; MARTIN, 2014; STIBBE, 2015; Van LIER, 2004; ). And though critical research may seem to have exhausted its range for innovation, new domains and conceptualizations are certain to arise in response to future concerns.

The notion of dialogue has one other application/exploration to which this introductory article in RBLA now turns. This notion of dialogue aligns with the narrative turn in the applied linguistic literature (BARCELOS, 2015; BARKHUIZEN, 2017; ZACCHI, 2016) a turn that illuminates research problems and possibilities in unique and personalized ways (see also CANAGARAJAH, 2012; WINDLE, 2017). For the task at hand (critical language teaching), narrative and other forms of personalized story telling should not be underestimated for its potential to mobilize the agency of the social actors involved. Toward this goal, the co-editors of this special issue on CLT will now utilize a more conversational, personalized structure for the remainder of this introductory article.

Brian Morgan: Andréa, in one of our recent conversations about this special issue you referred to a key tension or contradiction once raised by Walkyria Monte Mór, a contributor to this collection and a leading researcher and educator in critical literacies and language teacher education in Brazil. Walkyria observed, rightly I believe, that a core task of critical work involves challenging existing practices and habits of thought. Yet, 
this goal is often voiced in texts and discourses in ways that reproduce rather than transform academic and societal power relations, especially in respect to professional hierarchies that distance theorists from practitioners less familiar with privileged forms of meaning making (i.e., academic text production). Walkyria's point reminds us that, if we want critical work to be locally relevant, we should be open to exploring new and varied ways of talking about it and understanding it through the embodied experiences of students and community stakeholders, a perspective that is indebted to the work of Paulo Freire as many contributors to this issue note (see e.g. PESSOA; ANDRADE; FERREIRA, this issue; DUBOC; FERRAZ, this issue). In this respect, we can claim a rationale for a less formal introductory article, one that aspires towards dialogic possibilities as it unfolds.

Still, I recognize the challenge of this type of writing for those of us working in universities and whose career trajectories are increasingly subject to neoliberal pressures, not least of all, the need to be intensely "productive" - and to publish in highly ranked international journals (cf. the terrors of performativity, BALL, 2003), conforming to the literacy norms these journals require. For Brazilian scholars, the challenge is even greater, in that the highest measures of research impact come through Englishlanguage publications, requiring translation on many levels: linguistic code, formal academic genres, but also of historical, postcolonial experiences (cf. post-memory) and ways of knowing (epistemologies) not always appreciated or understood by center-based editors and reviewers, as Clarissa Jordão (2014) notes.

Let's see where this conversation takes us and what it does for our topic and the task of framing our special issue. Can it foreground and encourage a more organic criticality, one that addresses a Fear of Theory (SIMON, 1992), a resistance to ideas that challenge the ideological neutrality often claimed for language teaching and learning, but also a Fear of Pedagogy, the emotional and identity-based threat of classroom encounters that undermine our presumed authority and our deep investment in a scholarly life (see e.g., Anwarrudin's discussion of Rancière's work in this issue). This latter "fear of pedagogy", is also compounded by the low status of language teaching and its related research and theorizing in universities and societies. Such worldly conditions can lead us to an over-reliance on field-external theories and strategies from prestigious disciplines whose primary concerns may be marginally relevant to language teaching conditions and identities. A 
similar concern is raised by Tagata (this issue), who argues for greater selfreflexivity and contextual sensitivity in the ELT research community in order to break out of the "academic bubble" that constrains its transformative potential.

My thoughts on these issues have benefited greatly from our previous discussions and continuing ones with other Brazilian colleagues, starting from my first visit and critical literacies collaboration in 2011 with the Novos Letramentos Group and subsequent Brazil-Canada Knowledge Exchange project (TAVARES; BRYDON, 2013). Though I have been emphasizing the local so far, I recognize that it can also be a limiting and conservative perspective if not problematized. Indeed, it's been through transnational collaboration, as in the projects above, that I've come to recognize new critical opportunities in my own local sites of practice. In this regard, this RBLA special issue is enriched by the diversity of contributors and topics and the critical synergies that arise across their contributions.

Andréa Mattos: Yes, Brian, I agree with you in many ways and I'd like to pick up some of the points you make here. First, I want to start with the tension or contradiction you mentioned in the beginning, raised by Walkyria Monte Mor. As you know, she was my PhD Supervisor, and I remember very clearly when she first told me that we should try to look for alternative, more critical ways of reporting on our research projects, since we were working with Critical Literacies. For her (MONTE MOR, 2009, personal communication), these alternative ways should, as you said, challenge and try to transform academic practices and existing power relations in the Academy. However, this is easier said than done. I, myself, was very resistant to this idea when she first proposed it to me, and it took me a few months before I was ready to accept her suggestions for an alternative model to write my dissertation.

As I think back on these months of resistance now, while I listen to you talking about this Fear of Theory, I can't help thinking that this might have been the reason. It seemed so much easier to follow the traditional five-chapter model for writing theses and dissertations. Why did $I$ have to change? Why did I have to be different? Isn't it so much easier to stand on the dominant side? I finally complied and only now do I realize how much I have gained from this change! Taking "the road less traveled by", as Frost (1916) has put it, has allowed me to see the world from a different perspective 
and has opened up many doors in my academic career. The Brazil-Canada Knowledge Exchange (BRCAKE) project (TAVARES; BRYDON, 2013), as you remembered, starting from that first meeting in São Paulo in 2011, was certainly one of these doors, and many others followed.

However, there's more to it. Writing my dissertation in a different pattern might have seemed very challenging at the time, but I was still writing in Portuguese - my native language. After a few months of my $\mathrm{PhD}$ Examination, in July/2011, and thanks to the financial support of Dr. Diana Brydon, to whom we, participants of the Projeto Nacional (BRYDON; MONTE MOR; MENEZES DE SOUZA, 2010), are all highly indebted, some of us were invited to go to Glendon College, York University, in 2012, for a second round of the BRCAKE project. Oh! That was challenging! Sharing the round-table with you and Christine Smart-Wiseman, at Glendon, and some other Brazilian researchers, was among the few presentations in English that I had done thus far. Some years later, in 2016, I was invited for a conference at Ohio State University, and as I sat with Dr. David Bloome and his group of researchers and graduate students in a pre-conference conversation on a possible project, I remember when one of his colleagues referred to me, rather surprised, as being "so articulate in another language". I don't think he said that as a form of criticism to the fact that I was a non-native speaker of English and yet could express myself in the foreign language. In fact, I was flattered! Yet, I do feel that writing in English is at another level of challenge, a much higher one.

We live in a literate society (KRESS, 2000) and everything we write is recorded forever, especially when published on the web, as this special issue is. When we write in our native language, we don't realize the emotional labor of writing academic papers that non-native speakers go through, when writing in English. As English keeps "descending on us" (JORDÃO, 2016, p. 255), Brazilian scholars and researchers face ever-growing demands for publishing in English - or worse, for publishing in international journals in the English-speaking world. Our main supporting agencies - CAPES and $\mathrm{CNPq}^{1}$ - exert high pressure on graduate programs all over the country to

\footnotetext{
${ }^{1}$ CAPES stands for Coordenação de Aperfeiçoamento de Pessoal de Nivel Superior, or Coordination for the Improvement of Higher Education Personnel, and CNPq stands for Conselho Nacional de Pesquisa, or National Research Council. These are the two national agencies that provide financial support for researchers and university professors in Brazil.
} 
internationalize their publications, that is, to demand publications in English from their professors and students. These agencies tend to view the English language as a neutral code that can be translated from Portuguese on the basis of its grammar and vocabulary alone. This may be the case for more quantitative and/or hard-sciences research, such as Engineering, Biology, etc, but, in the Humanities and especially in more qualitative research, where the voice and identity of the researcher is highly present, the translation process may require more than attention to grammar and vocabulary. We, researchers and university professors in Brazil, need to find ways to resist these dominant practices and policies and, as Luke (this issue) puts it, to try and find strategies of counter-conduct to challenge the power relations in transnational settings. In my view, this dialogic introduction that we are working on together may be a form of this counter-conduct.

Brian: I remember that the 2012 BRCAKE panel you mention at Glendon College was on the topic of Critical Approaches to Identity and Citizenship in Language Teacher Education (LTE). The panel also included Leina Jucá and Sérgio Ifa from Brazil, and I can see from your account of the event that for you, and likely also for Leina and Sérgio, there were hidden or understated aspects of teachers' emotional labor (e.g. BENESCH, 2017; MILLER; GKONOU, 2018) around second/additional language use that Christine and I did not consider as part of our group discussion. It's also somewhat ironic that critical citizenship and teacher agency in LTE were key themes that day -- but without any discussion of the politics of unequal Englishes in the world (TUPAS, 2015) and the linguistic (pre) conditions needed to speak with authority, practice critical citizenship or discover and realize one's agency in a second/additional language. For teachers, self-perceived "inadequacies" in an L2 may pose an even greater emotional load in the area of global citizenship education given the dominant role of English as the language of participation and mobilization via social media (but see Chun's critique of the politics of social media in this issue). Transnational or global LTE projects using social media or telecollaboration would require some awareness of World Englishes as well as lingua franca and intercultural capabilities (JENKINS, 2015). At the same time, such a "non-standard" reorientation to English (and to language teaching in general) might not be appreciated or supported by Brazilian funding agencies, as you note above. 
A key issue here for critical work relates to language and identity. What language ideologies or theories of language do we offer teachers and students and what identity options and social possibilities do they suggest? In Brazilian LTE (as well as Canadian LTE!), I wonder if the introduction or promotion of more non-standardized linguistic models (e.g., English as a Lingua Franca, translanguaging, and plurilingualism) might provide effective counter-conduct (cf. LUKE, this issue; ANWARRUDIN, this issue; ROCHA; MACIEL, 2015) in respect to the hegemonic norms currently in place and the second/additional language insecurities they promote? Along this line of thinking, we could consider introducing students and teachers to what Joel Windle (2017, p. 382-384) describes as "subaltern Englishes in Brazil," the creative and hybrid practices of globally oriented youth. To our expanding list of "subversive" language models/ideologies, we could also add Miriam Jorge's (2012) work on the intersections of race and foreign language teaching in Brazil.

As a related example/model, López (in this issue) refers to the idea of an Indisciplinary Applied Linguistics (MOITA LOPES, 2006), and the need to politicize common sense beliefs around language and how it is taught and understood by learners. Of note, in her outline of Portuguese as a Welcoming Language (PWL), López does not promote the teaching of Portuguese as a neutral, standardized code, whose acquisition will overcome any barriers newcomers experience. Instead, she advocates for the teaching of Portuguese as a tool for self-defense for refugees/forced migrants and the prejudices they encounter in Brazil. From my reading of the López' article, I get a clear sense that this is an unusual and radical proposal for Portuguese language teaching, and I suspect that an unwelcoming reception would be extended to other foreign languages taught in a similar way. Yet, her notion of PWL exemplifies a critical approach based on the notion of language as a social practice.

Andrea: In this respect, I'd say Brazil has a lot to learn from Canada, both in teaching PWL, as suggested by López (this issue), but also in teaching English as an Additional Language (EAL). Critical perspectives in teaching EAL - or even English as a Foreign Language (EFL), for those who prefer to use this term - are just starting to become more frequent in the Brazilian scenario. In the very first years after the publication of the Orientações Curriculares para o Ensino Médio (High School Curricular Guidelines), the official 
educational document which introduced Critical Literacy in Brazil in 2006, many teachers were very resistant to the idea of teaching English from a critical perspective. As Valério and Mattos (this issue) point out, traditional practices are still the norm in many EFL/EAL classrooms in Brazil.

When I mentioned above the option for EFL, instead of EAL - a more recent term -, I should also say that I often prefer to refer to English as foreign language, exactly because the language is, to many learners in Brazil, foreign. In Portuguese, the word "foreign" is translated for estrangeira, but it also correlates with another similar word - estranha - which means strange. That's what English is to many learners: a strange language that is not easy to understand or learn, and many times learning this strange language, in adverse contexts as some of the contexts encountered in Brazil, hurts. In this respect, PWL as proposed by López (this issue) may be doing a better job. Also, teaching English from a critical perspective, as suggested by several of the articles in this issue, may open up better possibilities for both teachers and learners.

Brian: I'd say that Canada has a lot to learn from Brazil, and perhaps it's related to your point about the Brazilian experience of the English language as estranha, a "strange" and sometimes painful language to learn as well as to teach. This experience and awareness may explain what my colleague Ian Martin and I have often commented on while attending meetings and conferences in Brazil; that at least amongst the ELT or EFL (!) research community, there is a degree of critical conscientization (i.e., conscientização) around AL and LTE that is less prevalent in Canada.This may reflect, in part, the long experience and memory of (neo)colonialism, dictatorship, and the recent resurgence of right wing governments and authoritarian policies in education designed to reverse previous reforms (e.g., the "schools without parties" policy, DUBOC; FERRAZ, this issue; PESSOA et al., this issue). Perhaps these experiences and memories have become localized and internalized as part of the "strangeness" of English in Brazil you describe. The effect or influence I sense is a greater critical edge and strategic urgency (a growing dissensus that Tagata identifies, this issue), which seems to come through many of the contributions to this special issue.

In the Pessoa et al. article (this issue), for example, teacher proletarianization is specifically raised in the context of their critical LTE program. The word, itself, foregrounds class inequalities and the exploitation 
of workers, an adversarial and economic perspective on second/additional language teaching that most Canadians and ELT professionals (and professional LTE organizations) would be uncomfortable with in spite of strong evidence that testifies to the precariousness experienced by teachers of adult ESL in Canada (MORGAN, 2016). I sometimes worry that in Canada we are sleepwalking passively and incrementally into a kind of permanent (self) marginalization (cf. KUMARAVADIVELU, 2012), in which second/additional language teaching becomes at best a semi-skilled, part-time job or volunteer activity.

Again, I think there is much that can be learned from the work going on in Brazilian EFL/LTE, perhaps most importantly in the local, strategic ways in which critical practices are realized, and theorized, particularly in difficult times and repressive settings. Political upheaval and cultural wars increasingly impact education in North America, with policies openly hostile to involuntary migrants and Muslims, in particular, in the USA under the Trump administration (i.e., English as an Unwelcoming Language, cf. LÓPEZ, this issue). In Ontario, my home province in Canada, we have recently (June 2018) elected a conservative government whose immediate priorities are to cancel environmental protection programs, cut gasoline taxes, and suspend the province's progressive sex education curriculum, one that sought to promote respect for diverse sexualities in family and community life. How should we respond? As Christian Chun persuasively argues in this issue, we need critical ELT pedagogies and literacies that go beyond simply "naming" injustices and support community building and agency in the world beyond the classroom. This doesn't mean that we have to choose between the "conventional" and "critical" in our language curricula, but that we always need to look for synergies between the two, as you and your co-author have proposed in the development of a communicative EFL approach aligned with critical citizenship education (see VALERIO; MATTOS, this issue).

You and I have often talked about these kinds of grounded, localized approaches to critical language teaching, and as I mentioned above, these local practices or interventions are invigorated through the sharing of transnational insights and experiences.

Andrea: You are right. You and I have had quite a few chances of discussing these issues in our transnational meetings in São Paulo, Toronto, Aracaju, 
Winnipeg, and Campo Grande, together with several other colleagues from Brazil and Canada. I'd say this long-distance conversation has been rewarding for all of us involved in the BRCAKE Project and in Projeto Nacional. Perhaps this special issue on Critical Language Teaching may be seen as the culmination of the work we've been developing throughout these years, since 2011, and a tribute to how much we have learned from each other - in contrast to about each other, in Todd's (2003) terms. Drawing on the work of the French-Jewish philosopher Levinas, Todd speaks of ethical possibilities in education. In my view, this is also the project of Critical Literacies and other critical perspectives on language teaching, as we can notice through several - if not all - of the articles in this issue, especially from Christian Chun and Ana Paula López. A Canadian educator, Sharon Todd is very aware of colonial histories and of the roles that education has accomplished in Residential Schools in Canada and elsewhere. In this respect, Brazil and Canada share some commonalities: the colonial past and the violence exerted upon indigenous communities in both countries through education. Todd's discussion of ethics involves a consideration of "the powers and hazards of education, (...) its dangers as well as its aspirations" (p. 6-7). She is interested in putting forward a perspective of education as social justice and defends that "learning from as opposed to about allows us an engagement with difference across space and time (...); it allows for attentiveness to singularity and specificity within the plurality that is our social life" (p. 16).

Critical literacy as well as social justice education, as possible perspectives in language teaching, also caution against impositions of either dominant or alternative views in teaching (see, for example, HAWKINS, 2011; VALÉRIO; MATTOS, this issue). With Paulo Freire, the Brazilian educator, researchers with critical perspectives on language teaching in Brazil (for example, TAKAKI; MACIEL, 2014) have learned how education, as a transgressive practice, may be transformative and liberatory. We have also learned that education should be dialogic, a view that would involve not only teachers teaching students and students learning with teachers, but also teachers and students learning together. With Todd (2003), we learn from each other.

Brian: Nicely stated, Andrea! In the spirit of learning from each other, I hope that this special issue marks both a culmination and a new beginning for 
further collaboration on critical language teaching, inspired in large part by the articles in this special issue of RBLA. We invite readers to imagine and act upon the transformative possibilities that arise from these contributions.

\section{References}

ANDREOTTI, V.; MENEZES DE SOUZA, L. M. T. Learning to read the world through other eyes. Derby, England: Global Education, 2008. Available from http:// www.throughothereyes.org.uk/. Access on: 04 Jun. 2018.

ANDREOTTI, V.; MENEZES DE SOUZA, L. M. T. (Ed.). Postcolonial perspectives on global citizenship education. New York and London: Routledge, 2012.

APPLEBY, R.; PENNYCOOK, A. Swimming with sharks: ecological feminism and posthuman language politics. Critical Inquiry in Language Studies, v. 14, p. 239261, 2017.

BALL, S. J. The teacher's soul and the terrors of performativity. Journal of Education Policy, v. 18, p. 215-228, 2003.

BARCELOS, A. M. F. Unveiling the relationship between language learning beliefs, emotions, and identities. Studies in Second Language Learning and Teaching, Kalisz, Poland, v. 5, p. 301-325, 2015. Doi: https://doi.org/10.14746/ssllt.2015.5.2.6

BARKHUIZEN, G. (Ed.). Reflections on language teacher identity research. New York and London: Routledge, 2017.

BENESCH, S. Emotions and English language teaching: exploring teachers' emotion labor. New York: Routledge, 2017.

BRYDON, D.; MONTE MOR, W.; MENEZES DE SOUZA, L. M. T. Developing new literacies in cross-cultural contexts: future directions for teaching English in Brazilian and global contexts. In: MONTEIRO, M. C.; NUÑEZ, C. F. P.; BESNER, N. (Ed.). Diálogos nas Américas, Brasil/Canadá: culturas e literaturas. 2 ed. Rio de Janeiro: Caetés, v. 2, p. 1-105, 2010.

CANAGARAJAH, S. Teacher development in a global profession: an autoethnography. TESOL Quarterly, v. 46, p. 258-279, 2012.

CHUN, C.; MORGAN, B. Critical research in English language teaching. In: Gao, A. (Ed.). Springer Second Handbook of English Language Teaching. Norwell, MA: Springer Publishers, forthcoming.

CROOKES, G. V. Critical ELT in action: foundations, promises, praxis. New York: Routledge, 2013. 
DOUGLAS FIR GROUP. A transdisciplinary framework for SLA in a multilingual world. The Modern Language Journal, v. 100, Supplement 1, 2016. Doi: https://doi. org $/ 10.1111 / \operatorname{modl} .12301$

FROST, R. The road not taken. In: . Mountain interval. New York: Henry Holt and Company, 1916.

HAWKINS, M. (Ed.). Social justice language teacher education. Bristol: Multilingual Matters, 2011.

JANKS, H. Doing critical literacy: texts and activities for students and teachers. New York and London: Routledge, 2014.

JENKINS, J. Repositioning English and multilingualism in English as a Lingua Franca. Englishes in Practice, v. 2, p. 49-85, 2015. DOI 10.1515/eip-2015-0003

JORDÃO, C. M. Tradition and difference: can mainstream academic discourse in Applied Linguistics ever change? International Journal of Applied Linguistics, v. 25, p. 422-425, 2014.

JORDÃO, C. M. TEFL as Hydra: rescuing Brazilian teacher educators from "privilege". In: BUNCE, P.; PHILLIPSON, R.; RAPATAHANA, V.; TUPAS, R. (Ed.). Why English? Confronting the Hydra. Bristol: Multilingual Matters, 2016. p. 255-266. Doi: https://doi.org/10.21832/9781783095858-026

JORDÃO, C.; MARTINEZ, J. Z.; MONTE MÓR, W. (Ed.). Letramentos em prática na formação inicial de professores de inglês. Campinas: Pontes, 2018.

JORGE, M. Critical literacy, foreign language teaching and the education about race relations in Brazil. The Latin Americanist, p. 79-90, Dec., 17, 2012. Doi: https:// doi.org/10.1111/j.1557-203X.2012.01178.x

KASUN, G. S.; SAAVEDRA, C. M. Disrupting ELL teacher candidates' identities: indigenizing teacher education in one study abroad program. TESOL Quarterly, v. 50, p. 684-707, 2016. Doi: https://doi.org/10.1002/tesq.319

KRESS, G. 2000. Multimodality. In: COPE, B.; KALANTZIS, M. (Ed.). Multiliteracies: literacy learning and the design of social futures. London and New York: Routledge, 2000. p. 182-202.

KUBOTA, R.; MILLER, E. Re-examining and re-envisioning criticality in language studies: theories and praxis. Critical Inquiry in Language Studies, Taylor \& Francis Online, v. 14, issue 2-3, p. 129-157, 2017. Doi: https://doi.org/10.1080/154275 87.2017.1290500. 
KUMARAVADIVELU, B. Individual identity, cultural globalization and teaching English as an international language: The case for an epistemic break. In: ALSAGOFF, L.; RENANDYA, W.; HU, G.; McKAY, S. (Ed.). Teaching English as an international language. New York: Routledge, 2012. p. 9-27.

LÓPEZ-GOPAR, M. Decolonizing primary English language teaching. Bristol, UK: Multilingual Matters, 2016. Doi: https://doi.org/10.21832/9781783095773

MATTOS, A. M. A. English teacher critical education in Brazil. In: LIONTAS, J. I. (Ed.). The TESOL encyclopedia of English language teaching. Singapore: TESOL; Wiley Blackwell, 2018.

MILLER, E.; GKONOU, C. Language teacher agency, emotion labor and emotional rewards in tertiary-level English language programs. System, Elsevier, 2018 (ahead of print). Doi: https://doi.org/10.1016/j.system.2018.03.002

MOITA LOPES, L. P. (Org.). Por uma Linguistica Aplicada indisciplinar. São Paulo: Parábola, 2006.

MORGAN, B. Language teacher identity and the domestication of dissent: An exploratory account. TESOL Quarterly, v. 50, p. 708-734, 2016.

MORGAN, B.; MARTIN, I. Towards a research agenda for classroom-asecosystem. Modern Language Journal, v. 98, p. 667-670, 2014.

NORTON, B.; TOOHEY, C. Critical pedagogies and language learning. New York: Cambridge University Press, 2004.

PENNYCOOK, A. Critical applied linguistics: a critical introduction. Mahwah, NJ: Lawrence Erlbaum Associates, 2001.

PENNYCOOK, A. Language and mobility: unexpected places. Bristol: Multilingual Matters, 2012.

PENNYCOOK, A. Critical applied linguistics and education. In: McCARTY T.; MAY S. (Ed.). Encyclopedia of language and education: language policy and political issues in education. 3. ed. Cham, Switzerland: Springer, 2016.

PESSOA, R. R.; SILVESTRE, V. P. V.; MONTE MÓR, W. (Ed.). Perspectivas críticas de educação linguística no Brasil: trajetórias e práticas de professoras/es universitárias/ os de inglês. São Paulo, SP: Parábola, 2018.

RAJAGOPALAN, K. Por uma linguística crítica: linguagem, identidade e a questão ética. 3 ed. São Paulo, SP: Parábola, 2008.

ROCHA, R. F.; MACIEL, R. F. Ensino de língua estrangeira como prática translíngue: articulações com teorizações bakhtinianas. D.E.L.T.A., São Paulo, v. 31, n. 2, p. 411-445, 2015. 
STEPHENSON, S. V.; KRAMSCH, C. The ecology of second language acquisition and socialization. In: DUFF, P.; MAY, S. (Ed.). Encyclopedia of language and education: Language Socialization. 3rd ed. Cham, Switzerland: Springer, 2017. Doi: https:// doi.org/10.1007/978-3-319-02327-4_2-1

SIMON, R. Teaching against the grain: texts for a pedagogy of possibility. Toronto: OISE Press, 1992.

STIBBE, A. Ecolinguistics: language ecology and the stories we live by. New York: Routledge, 2015.

TAVARES, R.; BRYDON, D. (Ed.). Letramentos transnacionais: mobilazando o conhecimento entre Brasil/Canadá. Maceió: EDUFAL, Federal University of Alagoas Press, 2013.

TAKAKI, N. H.; MACIEL, R. F. (Ed.). Letramentos em terra de Paulo Freire. 3. ed. Campinas, SP: Pontes, 2017.

TODD, S. Learning from the other: Levinas, psychoanalysis, and ethical possibilities. Albany, NY: State University of New York Press, 2003.

TUPAS, R. (Ed.). Unequal Englishes: the politics of Englishes today. Basingstoke, UK: Palgrave Macmillan, 2015. Doi: https://doi.org/10.1057/9781137461223

Van LIER, L. The ecology and semiotics of language learning: a sociocultural perspective. Dordrecht: Kluwer Academic Publishers, 2004. Doi: https://doi.org/10.1007/14020-7912-5

WINDLE, J. Social identity and language ideology: challenging hegemonic visions of English in Brazil. Gragoatá, Niterói, v. 22, p. 370-392, 2017. Doi: https://doi. org/10.22409/gragoata.2017n42a894

WONG, S. Dialogic approaches to TESOL: Where the ginkgo tree grows. Mahwah, NJ: Lawrence Erlbaum Associates, 2011.

ZACCHI, V. J. A enxada e a caneta: linguagem e cultura na construção da identidade do sem-terra. São Paulo: FAPESP/Humanitas, 2016. 
http://dx.doi.org/10.1590/1984-6398201813938e

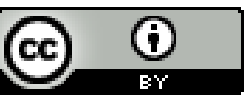

Erratum

In the article "Theories and Practices in Critical Language Teaching: A Dialogic Introduction", DOI: 10.1590/1984-6398201813938, published in the Brazilian Journal of Applied Linguistics, vol. 18, issue 2, p. 213-226, on pages 215: and 219:

Where you read: ANWARRUDIN

Now read: ANWARUDDIN 